\title{
Microstructure of internal carotid blood blister aneurysms under scanning electron microscope
}

Figure 1 Typical image of intracranial blood blister aneurysm (BBA)
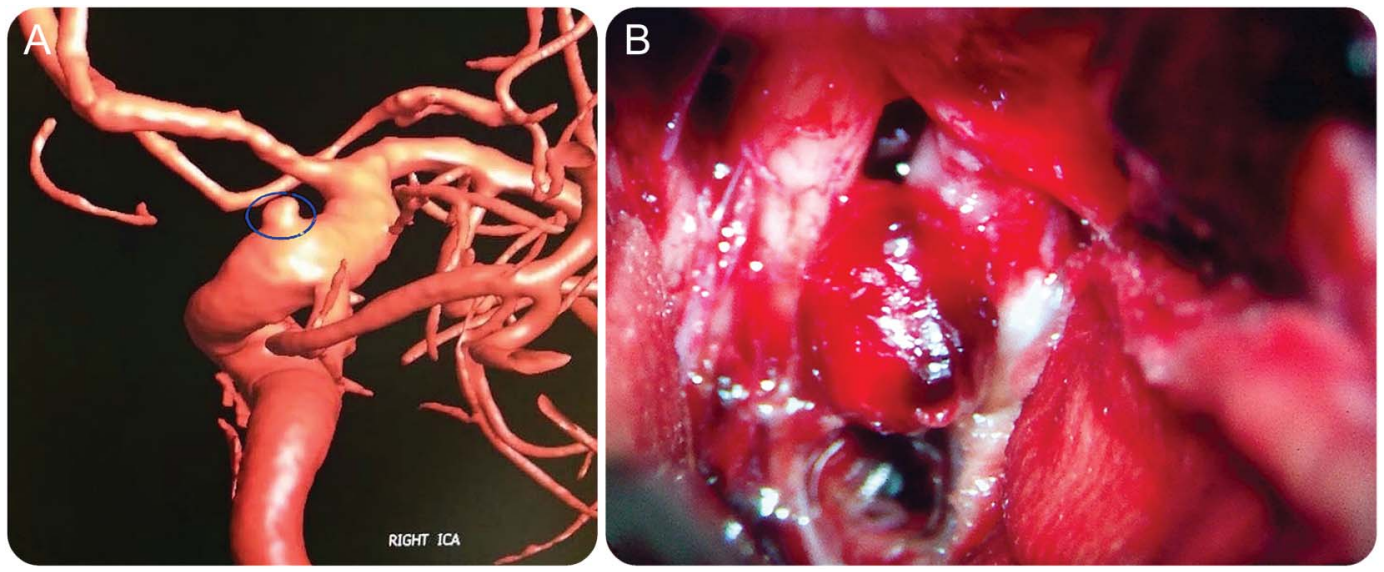

(A, B) A right internal carotid artery BBA on 3D digital subtraction angiography reconstruction and macrostructure during surgery.

Blood blister aneurysm (BBA) represents approximately $0.5 \%-2 \%$ of all ruptured aneurysms. ${ }^{1}$ The typical morphology of BBA is a small and fragile aneurysm sac with wide-necked hemispheric bulges at nonbranching sites of the supraclinoid internal carotid artery (ICA). BBA may originate from subadventitial dissection of the ICA. The focal gap is present in the internal elastic lamina and media, which is most often covered with thin lacerated fragmented adventitia and clot. We saw a Tibetan woman with a right BBA of ICA (figure 1). The patient underwent clipping surgery after the BBA ruptured. We present the different microstructure of BBA and ordinary aneurysm under scanning electron microscope (figure 2).

\footnotetext{
Figure 2 Comparison of ordinary intracranial aneurysm and blood blister aneurysm (BBA) under electron microscope
}
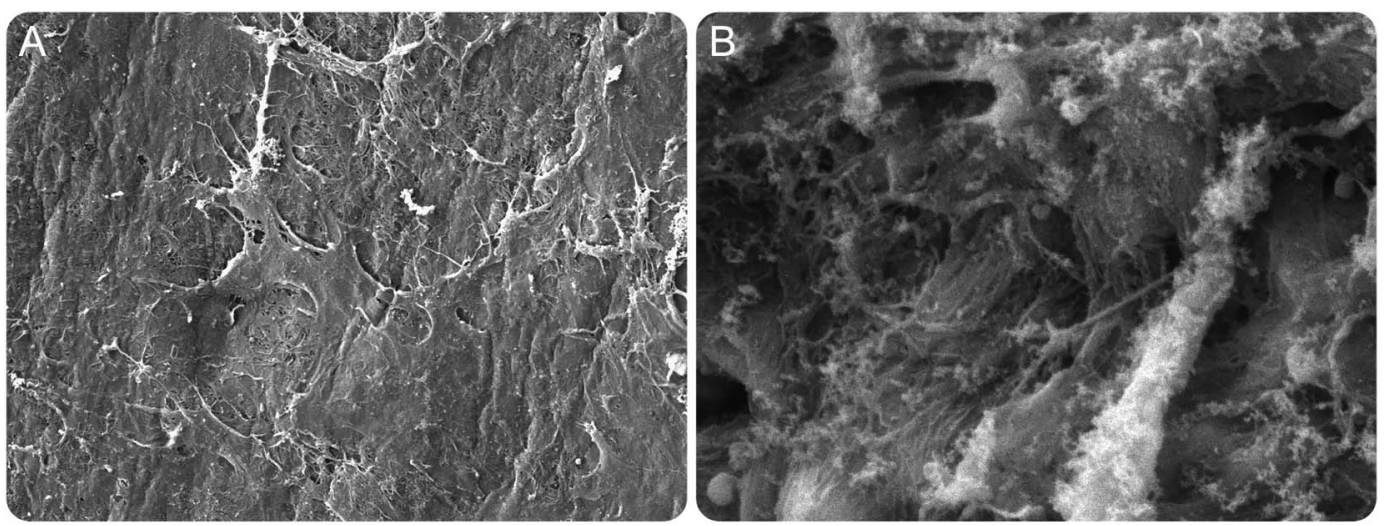

(A) Consistent and glossy surface of ordinary aneurysm. (B) Inconsistent and rough surface of BBA (under scanning electron microscope, magnification $\times 3,000$ ). 
From West China Hospital, Sichuan University, China.

Study funding: No targeted funding reported.

Disclosure: The author reports no disclosures relevant to the manuscript. Go to Neurology.org for full disclosures.

Correspondence to Dr. Ma: alex80350305@163.com

1. Gonzalez AM, Narata AP, Yilmaz H, et al. Blood blister-like aneurysms: single center experience and systematic literature review. Eur J Radiol 2014;83:197-205.

\section{Discover Altmetrics}

See real-time downloads and online activity for articles!

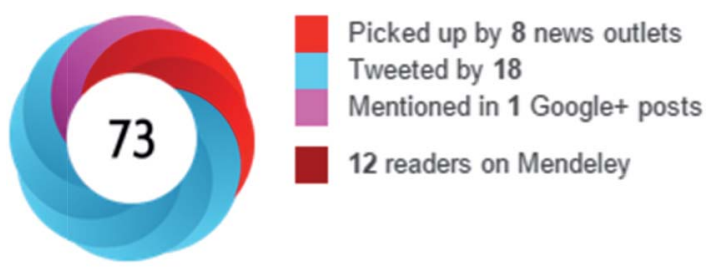

See more details

Authors and readers alike can view real-time data on articles including downloads and online activity across multiple sources. Click on the "Article Metrics" link in the right column of an article for details. To learn more about article metrics visit http://www.neurology.org/site/misc/article_usage.xhtml.

\section{Visit the Neurology ${ }^{\circledR}$ Resident \& Fellow Website}

Click on Residents \& Fellows tab at Neurology.org.

Now offering:

- Neurology ${ }^{\circledR}$ Resident \& Fellow Editorial team information

- "Search by subcategory" option

- E-pearl of the Week

- RSS Feeds

- Direct links to Continuum ${ }^{\circledR}$, Career Planning, and AAN Resident \& Fellow pages

- Recently published Resident \& Fellow articles

- Podcast descriptions

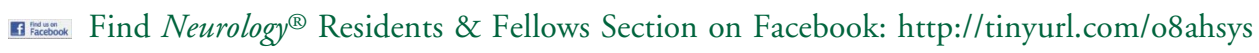

twitter Follow Neurology ${ }^{\circledR}$ on Twitter: http://twitter.com/GreenJournal 


\section{Neurology}

\section{Microstructure of internal carotid blood blister aneurysms under scanning electron microscope \\ $\mathrm{Lu} \mathrm{Ma}$}

Neurology 2017;88;1209-1210

DOI 10.1212/WNL.0000000000003748

\section{This information is current as of March 20, 2017}

\section{Updated Information \& Services}

References

Subspecialty Collections

Permissions \& Licensing

Reprints including high resolution figures, can be found at: http://n.neurology.org/content/88/12/1209.full

This article cites 1 articles, 0 of which you can access for free at: http://n.neurology.org/content/88/12/1209.full\#ref-list-1

This article, along with others on similar topics, appears in the following collection(s):

All Cerebrovascular disease/Stroke

http://n.neurology.org/cgi/collection/all_cerebrovascular_disease_strok e

All Imaging

http://n.neurology.org/cgi/collection/all_imaging

Information about reproducing this article in parts (figures,tables) or in its entirety can be found online at:

http://www.neurology.org/about/about_the_journal\#permissions

Information about ordering reprints can be found online:

http://n.neurology.org/subscribers/advertise

Neurology ${ }^{\circledR}$ is the official journal of the American Academy of Neurology. Published continuously since 1951, it is now a weekly with 48 issues per year. Copyright () 2017 American Academy of Neurology. All rights reserved. Print ISSN: 0028-3878. Online ISSN: 1526-632X.

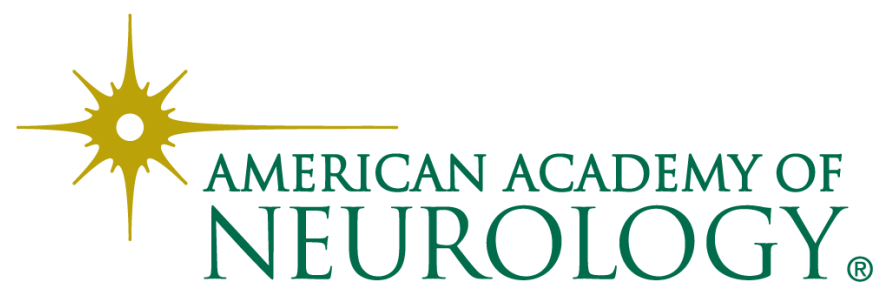

